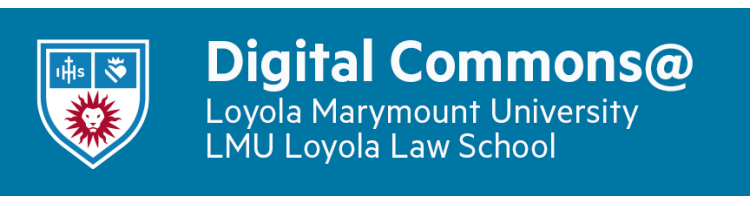

Journal of Catholic Education

\title{
What Secondary Teachers Need in Professional Development
}

Lisa Lucilio

Follow this and additional works at: https://digitalcommons.Imu.edu/ce

\section{Recommended Citation}

Lucilio, L. (2009). What Secondary Teachers Need in Professional Development. Journal of Catholic Education, 13 (1). http://dx.doi.org/10.15365/joce.1301042013

This Article is brought to you for free with open access by the School of Education at Digital Commons at Loyola Marymount University and Loyola Law School. It has been accepted for publication in Journal of Catholic Education by the journal's editorial board and has been published on the web by an authorized administrator of Digital Commons at Loyola Marymount University and Loyola Law School. For more information about Digital Commons, please contact digitalcommons@lmu.edu. To contact the editorial board of Journal of Catholic Education, please email JCE@nd.edu. 


\title{
What Secondary Teachers Need in Professional Development
}

\author{
Lisa Lucilio \\ Notre Dame Academy, Ohio
}

\begin{abstract}
Most dioceses do not have well-articulated, systematic approaches to the professional development of Catholic school teachers and administrators. This article summarizes current research on effective strategies for professional development and reports on a study of one Midwestern diocese regarding the needs, perceptions, and plans of teachers and principals at the high school level.
\end{abstract}

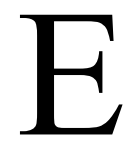

ducation has been a topic of national debate during the past two decades. Political, social, and educational reformers have noted the impact of schools as one vehicle in bringing about the improvement of society for the benefit of all citizens, which is the aim of all noble reform. Any education reform movement cannot begin to consider itself successful, or be recognized, unless it includes the teacher. In reality, any reform effort has to go through the teacher and cannot be accomplished without the teacher. It is the teacher who will ultimately determine what is introduced, attempted, and included in the classroom experience.

The teacher, what happens in the classroom, and activities that help facilitate learning are major influences in student achievement. The teacher is at the center of what takes place in the classroom. The teacher is responsible for creating a student-centered, stimulating, and developmentally appropriate learning environment. As teachers are the architects of the classroom, professional teacher development and teacher education are the architects of the teacher. Professional development prepares the teacher to be an active force in improving student achievement. Professional development must include the teacher in all phases of its advancement. The purpose of this study was to determine differences and similarities between administrators' and teachers' views on professional development for secondary educators in Catholic high schools in the Diocese of Toledo, Ohio. 


\section{Review of the Literature}

Research on professional development is varied and widespread. Limited research is available on secondary educators with even less documentation on what is needed to improve teaching and learning for all students and how to evaluate professional development experiences. Guskey (1994) recommended the following guidelines for successful professional development: address change as an individual and organizational process; think big in planning and implementation, but start small, keeping the big picture in mind; work in teams to maintain support; include procedures for feedback on results; provide continued follow-up, support, and pressure for improvement; and integrate programs, as no one idea will address all issues. Little (1999) found that students first experienced professional development aimed at improving student achievement through individual teachers and that the quality of teaching mattered in terms of student achievement more than new models, programs, and structures. Little concluded that the quality of teaching and the student-teacher relationship matter most in terms of what schools can achieve with students.

If this is true, it seems reasonable to suggest that all professional development and its success in bringing about improved student achievement begin with the teacher and quality teaching. Teachers must be the first ones consulted when assessing what is needed to improve the classroom and learning. Unfortunately, teachers seem to be a late addition, consulted only after decisions about professional development and program implementations have already been determined by administrators or curriculum specialists who are too far removed from the daily interactions of the classroom. Usually professional development literature is grouped together and not separated into primary, middle, or secondary teaching. Although there are different needs for each group, there are also professional development areas that overlap. Catholic schools, though a little different in their design, are similar in their professional development programs.

\section{Teacher Education and Professional Development}

A rich learning environment needs to be established throughout a career, from the beginning teacher to the most advanced professional. Professional teacher development has many critics. Effective professional development addresses the flaws of traditional approaches, which are often criticized for being fragmented, unproductive, inefficient, unrelated to practice, and lacking in intensity and follow-up (Fullan, 1993; Guskey, 1994, 2000; Holmes Group, 1986, 1990, 1995; Little, 1999; No Child Left Behind [NCLB], 2001). Abdal-Haqq 
(1996) states effective professional development (a) is ongoing; (b) includes training, practice, and feedback; and (c) includes opportunities for individual reflection and group inquiry into practice and coaching or other follow-up procedures. Specifically, Abdal-Haqq describes effective professional development as school based and embedded in teacher work, which includes collaboration, focuses on student learning, which should, in part, guide assessment of its effectiveness, and encourages and supports school-based and teacher initiatives. Abdal-Haqq also states effective professional development is rooted in the knowledge base for teaching, incorporates constructivist approaches to teaching and learning, recognizes teachers as professionals and adult learners, provides adequate time and follow-up support, and is accessible and inclusive.

The National Education Commission on Time and Learning (NECTL) (1994) reported in Prisoners of Time that what teachers are expected to know and do has increased in amount and complexity. Reforms demand that teachers improve subject matter knowledge and pedagogical skills, understand cultural and psychological factors that affect student learning, and assume new and greater responsibilities for curriculum, assessment, and professional collaboration (Bull, Buechler, Didley, \& Krehbiel, 1994; Corcoran, 1995; NECTL, 1994). The National Commission on Teaching and America's Future ([NCTAF], 1996) points out that the current teaching force averages 14.5 years of teaching. These teachers were prepared when teaching did not routinely require many of the skills that are needed to function effectively in schools today. This situation has led to a redefining of professional teacher development and its role in large-scale reform initiatives (NECTL, 1994).

Lack of time is the greatest challenge to effective professional teacher development. Prisoners of Time (NECTL, 1994) reports that students and teachers are victims of inflexible and counterproductive school schedules. The report observes that professional development typically takes place before school, after school, during the summer, or on scattered teacher in-service days, which impose on teachers' personal time during preparation periods and cut into time needed for other day-to-day teacher tasks. The report also states that teachers who sacrifice this personal time often experience burnout from competing demands for their time and that professional development has not been seen as an intrinsic part of making teachers more successful in the classroom. Schools do not typically allow time to consult or observe colleagues or engage in professional research, learning and practicing new skills, developing curriculum, or reading professional literature. Administrators, parents, and legislators may also view anything that takes teachers away from the 
classroom unfavorably, and teachers themselves often feel guilty about being away from their classrooms.

Watts and Castle (1993) identify innovations from a National Education Association school survey for finding time for teachers and professional development:

- Freed-up time: Using teaching assistants, college interns, parents, and administrators to cover classes and regularly scheduling early release days.

- Restructured or rescheduled time: Lengthening the school day on 4 days with early release on day 5 .

- Better-used time: Using regular staff or district meetings for planning and professional growth rather than for informational or administrative purposes.

- Common time: Scheduling common planning periods for colleagues having similar assignments.

- Purchased time: Establishing a substitute bank of 30-40 days per year that teachers can tap when they participate in committee work or professional development activities.

Guskey (2000) stated that all teachers committed to teaching all students must be learning all the time, but a long history of poor professional development experiences does not give much hope that student achievement will be improved. Guskey argued that staff development must focus on content and methods and be linked to daily classroom experiences in order to affect student learning. Many professional development experiences are provided top down from administrators and are isolated from the classroom, and hence will never influence practice. Many teachers and administrators, Guskey noted, have a narrow view of professional development, such as attending in-service days or taking graduate courses in order to obtain the required number of hours or credits to keep their teaching license or advance in their career. This takes the focus of professional development from improving methods to attaining required hours.

Guskey (2000) defined professional development as "those processes and activities designed to enhance the professional knowledge, skills, and attitudes of educators so that they might, in turn, improve the learning of students" (p. 16). The ultimate goal of all professional development must be to improve practice in order to help all students achieve their full potential. This goal must be the constant driving force for all educators concerning professional development.

Professional development can be divided into seven major categories (Guskey, 2000), each with its own strengths and weaknesses (see Figure 1). 
Training - This includes large group presentation and discussion, workshops, and seminars that include theory, modeling of skills, simulated practice, feedback, and workplace feedback. This is most efficient and cost effective, but leaves little time for choice or individualization.

Observation/Assessment - This method is defined by peer observation to provide feedback on teaching that includes coaching and clinical supervision, and can focus on lesson plans, instructional practices, and class management. This should be followed by careful analysis, explanation, and reflection to lead to real improvement for both participants. This method takes a great deal of time and coordination, and observation must be evaluated.

Involvement in a Development/Improvement Process - This includes curriculum committees, designing new programs to improve instruction, or problem solving. This allows committee members to gain in-depth knowledge of a specific issue and work together, but typically only a small number of people are involved in the process.

Study Groups - This method involves the entire school staff in solving a common problem. Members are placed into groups of 4-6 and continue for the year with each group focusing on a specific aspect of the problem. Effective groups are well organized and focused, and have sufficient time to complete their work. If not carefully structured, groups can be dominated by one member with others not involved and groups may become opinion based, not fact based.

Inquiry/Action Research-This method is based on the belief that teachers are thoughtful, inquiring, and inclined to solve problems and search for answers to pressing questions. It usually involves six steps: selecting a problem, collecting information related to the problem, studying professional research on the problem, determining possible actions to achieve goals, taking action, and documenting results. This helps narrow the gap between practice and research, but takes a great deal of time.

Individually Guided Activities - Teachers develop their own individual professional goals and activities that will achieve those goals. The process starts with identifying a need or interest, developing a plan to meet that need or interest, learning activities, and assessing to determine if learning has met the goals or interests stated. This provides choice, flexibility, and individualization, but goals must be challenging, worthwhile, and relate to specific improvements in classroom practice.

Mentoring - This method pairs an experienced educator with a less experienced educator. Time is spent developing professional goals, practices, and strategies, and reflecting on teaching and learning. This is highly individualized and provides professional opportunities for both individuals. Mentors must be skilled in ways of adult learning and this should also be combined with other forms of professional development to broaden the experience.

Figure 1. Guskey's (2000) seven major categories of professional development.

Staff development can be implemented in three forms: district-wide, sitebased, or an integrated design. Site-based designs are more likely to be contextually relevant and give a strong voice to those directly involved in the local school community. District-wide designs offer a broader vision for improvement, provide an extended opportunity for sharing ideas and resources, 
allow for collaboration across school levels, and are efficient. Integrated designs combine site-based and district-wide designs to produce a professional development program that typically begins with a district-wide presentation that is then further developed at each school. Overseeing all of the above, effective professional development must have a clear focus on learning and learners, place an emphasis on individual and organizational change, work for small changes guided by a grand vision, and support ongoing professional development that is procedurally embedded (Guskey, 2000).

\section{Recent Improvements in Education Reform}

Since the Holmes Group reports (1986, 1990, 1995), NCTAF (1998, 2003), and the improvements of National Center for Accreditation for Teacher Education ([NCATE], 2007) during the early and mid-1990s, much has improved in teaching and teacher education. These earlier reports resulted in more rigorous standards and improvement in subject content knowledge and how to teach that content to students. The Holmes Group, NCTAF, and NCATE support the statement that investment in teacher professional development is among the most productive means to increase student learning (Darling-Hammond, 2000).

Darling-Hammond (2000) writes, "In every category of possible investment in teachers' knowledge and in every area in which standards for teaching are set, there are substantial differences in the policies and practices employed by states, and these differences influence what students learn" (p.15). After controlling for student characteristics, such as poverty level and language, the strongest predictor of student achievement on the National Assessment of Educational Progress (NAEP) was the proportion of wellqualified teachers (Darling-Hammond, 2000). NCTAF (2003) stated that more than 2,000 articles and editorials; national reports; national, state, and local legislation; and long-term commitments to high-quality teaching have occurred since its original report in 1996. All of this has built a consensus that high-quality teaching is the most important factor in a student's education. The number of NCATE accredited institutions has grown from 481 to 548 in 6 years. The National Board for Professional Teaching Standards (NBPTS), which documents accomplished teaching in veteran teachers, and the Interstate New Teacher Assessment and Support Consortium, which includes more than 30 states and determines standards for beginning teachers, have set rigorous licensing standards for pre-service and professional educators. NBPTS has certified 23,930 teachers nationally, and 48 states provide incentives for NBPTS certification. The number of National Board certified 
teachers has more than doubled in the past 5 years, from more than 32,000 in 2003 to nearly 74,000 in 2008 (NBPTS, 2008). Forty-eight states have signed the National Association of State Directors of Teacher Education and Certification contract granting license reciprocity among members (NBPTS, 2008). The average teacher's salary has increased from $\$ 37,564$ in 1996 to $\$ 49,109$ in 2006 (National Center for Education Statistics [NCES], 2007). Reciprocity allows teachers to relocate and be able to continue their careers without having to get recertified. Increased salaries allows education to keep good teachers in the classroom who might have moved on to higherpaying positions.

NCTAF (2003) developed a three-part strategy in order to put a qualified teacher in every classroom by 2006 . The main goal of these reports:

- States must organize every school for teaching and learning success. Although this was originally the commission's fifth recommendation, it is now its highest priority.

- States must insist on quality teacher preparation, accreditation, and licensure. Quality preparation pays big dividends.

- States must develop and sustain professionally rewarding career paths for teachers, from mentored induction through accomplished teaching.

NCTAF gave five recommendations for change that will support school success, increase teacher retention, strengthen teacher quality, and improve student achievement: Encourage teacher collaboration and differentiated staffing, share instructional leadership among teachers and principals, redesign and downsize schools into small learning communities, support the vision with technology, and prepare new teachers in close collaboration with these schools and support their continuous professional development. These strategies and recommendations provide a possible starting point in improving teacher preparation programs and in implementing professional development opportunities for continuing educators.

NCTAF (2003) recommended that collaboration be incorporated into every school building and every teacher's work. Exceptional teachers should be mentors and educational leaders among their colleagues. Schools should build collaborations with universities and keep up on the latest educational research. Teachers also need to share in the leadership and decision-making process of their school buildings and school districts. Sharing leadership creates a feeling of ownership and responsibility in working to ensure achievement for all students. NCTAF also recommended small school size because small schools are associated with improved student achievement, improved attendance rates, higher graduation rates, and higher grades. NCTAF reaffirmed 
that time for professional development is essential for professional growth. "Teachers need time to reflect on student learning needs, time to work with colleagues, time to observe, time to plan and collaborate, time to reflect on what is working, and time to take a step back and evaluate" (p. 130).

Since the passage of the No Child Left Behind Act (2001), each state is to work toward placing a highly qualified teacher in every classroom by 2005-2006. In 2008-2009 this goal has not yet been achieved. About 22\% of high school teachers do not have a major or minor in the subject area they teach (Beaver, 2004). Forty-two states during 2004-2005 used Praxis II to measure content knowledge of future teachers. However, what qualifies as a passing score on the test varies from state to state. Beaver states that each year one-third of graduating education majors pursue other careers and another third leave education after 5 years. NCTAF recommended that all school districts develop support programs for new teachers, promote teachers' continued growth, recognize accomplished teaching, and provide compensation and working conditions for teachers that respect their professional standing in American society.

\section{Catholic Schools: Different by Design}

In the 2007-2008 academic year, 637,378 students were enrolled in Catholic secondary schools and almost 2.3 million students were enrolled in Catholic elementary schools (National Catholic Educational Association, 2008). During the same period, projected enrollment in public elementary and secondary schools was 49.6 million (NCES, 2007). Thus, roughly $4.4 \%$ of all students attended a Catholic school during the 2007-2008 academic year.

Research reveals that Catholic schools emphasize a core academic curriculum with a modest range of electives, support teachers' expectations for academic mastery, hold students accountable for their own academic performance, support students before and after school, and emphasize development of the whole student concerned with the kind of persons students become as well as what they know (Bryk \& Holland, 1984; Bryk, Lee, \& Holland, 1993). Students are viewed as whole persons to be educated rather than as distinct intellectual capacities to be advanced or particular problems to be solved. Teachers often describe their role as ministry in helping to shape young adults. Research also supported that Catholic school educators view their role with students as more facilitative, having less dictates in the classroom than public school teachers, and tending to encourage more of an atmosphere of openness, cooperation, and student self-monitoring (Shimabukuro, 2001). 
Empirical research on the role of the Catholic school teacher is minimal and professional development of Catholic school educators is no exception. A document from the Vatican concerning education, The Catholic School on the Threshold of the Third Millennium (Congregation for Catholic Education, 1997), stated that the role of teacher has expanded to include stages of life, situations beyond the classroom, new content, and new educational models. Teaching has become more complex and specialized, making it more difficult. The role of the Catholic school teacher has developed since Vatican II to include a shift from traditional to progressive pedagogy, from teacher centered to learner centered, from authoritarian to participative, from academic achievement to lifelong learning, from rote teaching and learning to teaching for understanding, from uniformity to meeting individual needs, and from parochialism to global awareness. Some of these trends are noted in public education, some are uniquely Catholic, and all are carried out within a Catholic framework (Shimabukuro, 2001).

Traviss (2001) states that Catholic school leadership seems to be viewed in a different manner by teachers compared to administrators. Lay and religious teachers want more shared decision-making participation in the areas of curriculum and instruction programs. Teachers' perceptions of their principals' leadership style influenced perceptions they had of themselves as a staff. Teachers felt disengaged from school decisions, especially concerning budget and staffing. This contradicted trends that report Catholic school administrators are moving toward a more transformational and shared form of leadership. Teachers and administrators seem to view leadership and what actually happens in schools differently. Bureaucratic control has a dysfunctional consequence for integrated leadership and instrumental effectiveness in Catholic schools.

Rogus and Wildenhaus (2000) add that principals and leaders of Catholic schools must remember that their primary purposes in staff development are to free teachers to refine their gifts so they are better able to serve students; to provide a strong informal program that allows teachers to view themselves as strong, contributing professionals; and to provide faculty members a variety of opportunities for professional growth and models for spiritual formation. The call is to provide a comprehensive program that is both formal and informal. This can best be accomplished when all interactions with faculty are viewed as having staff development implications, when there is a clear distinction between formal and informal staff development, when a strong formal and informal staff development program is implemented, when specific program priorities are identified, and when basic program implementation guidelines are honored. 
In order for strong formal and informal staff development programs in Catholic schools to succeed, Rogus and Wildenhaus (2000) concluded that teachers must be involved in developing shared school goals, collaborating, engaging actively in their own learning, developing a command of the knowledge of the profession, discussing with other professionals, and committing themselves to making a difference in the lives of children. An educational leader must express appreciation and recognition for the work of teachers, be caring and humorous, allow for experimentation while maintaining high standards, provide tangible support for faculty projects, maintain a knowledge base of the field, protect the values that are important to the faculty, and, most importantly, maintain open and honest communication. In order to improve professional development, a paradigm shift is desperately needed to embody the notions of self-determination, self-assessment, and personalized planning. This paradigm shift includes both the individual and organizational dimensions of professional development and an assessment process that evaluates staff development based on student learning. Professional educators must be supported as they assume increasing responsibility for their own professional growth and increased student achievement. Due to the daily nuts and bolts of classroom teaching, these things are much easier stated than accomplished (Rogus \& Wildenhaus, 2000).

The questions to be asked concerning professional growth are: (a) What is really important to teachers in Catholic schools? (b) What inspires them? (c) What motivates them? and (d) What discourages them from readily embracing staff development efforts? Interpersonal themes such as working with others and service are frequent reasons given for becoming a professional educator. Moore (2000) sums up the obstacles facing good professional development by making the point that the culture of school often works against effective staff development. The "classroom press" draws focus on daily tasks, isolates teachers from one another, exhausts energy, and provides limited opportunity for professional reflection. Communication between teachers and with administration is limited because of the way schools are organized and administered. Frequently, most teachers soon find teaching to be a very private experience reinforced by individualism and isolation. Many beginning teachers describe feelings of uncertainty and a poorly defined technical culture, which goes against the reasons they desired to become teachers (Lortie, 1975; Moore, 2000). Today, teachers are being called to base teaching practice on sound moral and educational principles, within a learning community in which all members can work each day in a climate of trust and respect, empowered to grow both personally and professionally. Change is necessary to accomplish this. Teachers must be willing to overcome resistance and fear 
in order to achieve greater personal and school-wide growth with the ultimate goal the well-being of all students.

\section{Statement of the Problem}

NCTAF (1996) proposed a national educational goal that by 2006 all students should have access to competent, caring, and qualified teachers. Although improvements in placing qualified teachers in every classroom have been achieved, in 2009, this goal has not been accomplished. In order to achieve this goal, professional teacher development and teacher education must be improved. The problem begins when teachers and administrators are not in agreement on how to accomplish this goal.

NCTAF collected data that may be considered indicators of teaching and teacher quality. The NCTAF (1996) report, What Matters Most: Teaching for America's Future, started from three simple premises:

- What teachers know and can do is the most important influence on what students learn.

- Recruiting, preparing, and retaining good teachers is the central strategy for improving our schools.

- School reform cannot succeed unless it focuses on creating the conditions in which teachers can teach, and teach well.

The commission, after a 2-year study, then identified critical barriers to achieving this goal. Barriers included low expectations for student performance, unenforced standards for teachers, major flaws in teacher preparation, painfully slipshod teacher recruitment, inadequate induction for beginning teachers, lack of professional development and rewards for knowledge and skill, and school structures that promote failure rather than success.

NCTAF then offered five major recommendations to address these concerns and achieve its stated goal. These recommendations included the following, which are linked to professional development: Getting serious about standards for both students and teachers, reinventing teacher preparation and professional development, fixing teacher recruitment and putting qualified teachers in every classroom, encouraging and rewarding teacher knowledge and skill, and creating schools that are organized for student and teacher success. These major recommendations specifically include establishing professional standards boards in every state; organizing teacher education and professional development programs around standards for students and teachers; creating stable, high-quality sources of professional development; aggressively recruiting high-need teachers and providing incentives for teach- 
ing in shortage areas; and selecting, preparing, and retaining principals who understand teaching and learning and who can lead high-performing schools.

Teaching is one of the few professions that is requiring more of its practitioners to become certified/licensed and may not always reward those practitioners who successfully increase their skills. Many undergraduate education programs now require 4.5 or even 5 years to complete. These teacher education programs are designed to produce the best and most competent preservice teachers ready to begin careers as professional educators. Students successfully completing the program must now pass the National Teacher Exam in many states. All of this preparation does not guarantee success, or even confidence. Even with many states requiring entry-year mentoring programs, many beginning teachers often find themselves isolated with no sense of support when difficulties arise. Many believe they will be viewed as incompetent if they ask for help. It is a time of great excitement and enthusiasm, but can also be a time of great frustration and loneliness. Professional development opportunities and collaborating with colleagues can help overcome these obstacles to improving the quality of teaching.

Career educators can be costly to a school district because of graduate degrees or national certification recognition. Many school districts offer large retirement buyouts to experienced teachers in order to hire less experienced teachers at a cheaper cost. What statement does this make about the value and priority of professional educators and the ability to attract the best candidates as teachers? More is being asked of teachers in the classroom, but even more is being demanded of teachers in their professional development. Yet, little is being done to support professional educators in these efforts to improve the quality of teaching and teachers. In 2001, 33 states required mentor programs but only 22 funded mentor programs (NCTAF, 2003). In 2001 there were 16,000 National Board certified teachers out of a total teaching force of 3.4 million, with a projection of 25,000 National Board certified teachers for 2002 (NCTAF, 2003). In 2002, 33 states offered financial rewards for National Board certified teachers (NCTAF, 2003). These along with many other factors contribute to the quality of teaching students receive in the classroom and the acceptance of teachers as true professionals in education.

A model, exceptional, lifelong, professional educator never ceases from being a student of teaching and learning. Reforms are slow, but they are occurring. Teachers are being asked to do more with less, and are doing it successfully. Professional teacher development has taken many forms and few assessments have been carried out to determine which are most successful at improving teacher effectiveness and raising student achievement. What experiences do teachers and administrators believe will best assist secondary 
educators in improving classroom teaching with the ultimate goal being to improve achievement for every student so that no child is left behind?

\section{Methodology and Results}

This study attempted to identify differences and similarities among Catholic teachers, school administrators, and diocesan administrators regarding professional development for secondary educators. Specifically, what does each group believe are the most needed topics in professional development opportunities and how are they best delivered? This study also attempted to determine the most efficient manner of providing professional development opportunities for secondary educators and how to provide better professional development experiences for both secondary teachers and administrators.

\section{Population}

The study population consisted of teachers and principals from the 14 Catholic high schools in the Diocese of Toledo and the diocesan administrators from the Catholic schools office, which services all schools in the Diocese of Toledo. The Catholic schools office in Toledo serves 83 elementary schools with 21,714 students, 10 diocesan and parish high schools with 3,884 students, four private high schools with 2,852 students, and two colleges and universities (Toledo Catholic Diocese, 2003).

\section{Demographics of the Sample}

Surveys were mailed to 14 Catholic high schools in the Toledo diocese and to diocesan administrators in the spring of 2002 after introductory phone calls were completed. A second reminder was mailed and phone calls made to schools that did not respond in late spring. All teachers and administrators were asked to complete and return the survey. Of the 545 surveys mailed, 169 valid surveys were returned for a $31 \%$ return rate. Responses were received from all 14 high schools and the diocesan central office. A total of 20 school administrators returned completed surveys from 8 of the 14 diocesan high schools. Eight diocesan administrators returned completed surveys, and 141 out of roughly 500 diocesan teachers returned completed surveys.

Respondents can be further categorized by years in education and degree earned. Fifty (29.6\%) respondents had 26 or more years in education, 46 (27.2\%) had between 6 and 15 years, 44 (26\%) had between 16 and 25 years, and $27(16 \%)$ had 5 years or less experience in education. Eighty-five (50.3\%) of the respondents had earned a master's degree, $76(45 \%)$ had earned at least a bachelor's degree, and $6(3.6 \%)$ had earned a doctorate. Since the 2003- 
2004 school year, the majority of respondents (113 or 66.9\%) had attended 5 or fewer professional development opportunities, $40(23.7 \%)$ had attended between 6 and 10, and $16(9.5 \%)$ had attended 11 or more. Fifty-nine $(34.9 \%)$ of the respondents were male and $103(60.9 \%)$ were female.

\section{Comparisons of Most Beneficial In-Service Methods}

Teachers $(n=139)$, school administrators $(n=20)$, and diocesan administrators $(n=8)$ were asked to rank the most beneficial in-service method from a list of 7 choices (see Table 1). This reflects the literature reviewed that criticized traditional professional development as fragmented, inefficient, and unrelated to practice (Abdal-Haqq, 1996; Fullan, 1993; Guskey, 1994, 2000; Holmes Group, 1986, 1990, 1995; Little, 1999; NCLB, 2001). Effective professional development was characterized as ongoing and included training, practice, and feedback as well as opportunities for reflection and feedback. Given the mean rankings, it is clear that teachers have a clear idea of the most beneficial in-service method with hands-on participation and demonstration being the most valued. School administrators agreed with teachers on the two most beneficial in-service methods, but ranked demonstration first and hands-on participation second as the most beneficial in-service method. School administrators ranked the seminar method much higher than classroom teachers. School administrators agreed with the teachers' ranking on the remaining four in-service methods. Diocesan administrators had a greater range in their mean rankings of in-service methods than teachers and school administrators. Mean rankings for diocesan administrators had demonstration as the top in-service method, but hands-on participation was ranked fifth, compared to first and second for teachers and school administrators, respectively. Diocesan administrators ranked the lecture/discussion method second and the seminar method third. Teachers ranked the seminar method last. The only significant difference was found between teachers and school administrators, with teachers viewing the seminar method as a significantly less beneficial in-service method than school administrators.

\section{Comparison of Most Effective Means of Implementing Staff Development}

Teachers $(n=138)$, school administrators $(n=20)$, and diocesan administrators $(n=8)$ were asked to rank $(1=$ most effective, $3=$ least effective $)$ the most effective means of implementing staff development from three choices of diocesan-wide, school-wide, or an integrated approach using both (see Table 2). These survey questions reflect Guskey's (2000) work with each of the approaches to professional development and their strengths and weaknesses 
Table 1

Most Beneficial In-Service Methods Mean Rankings

\begin{tabular}{lccc}
\hline & Teachers & $\begin{array}{c}\text { School } \\
\text { administrators }\end{array}$ & $\begin{array}{c}\text { Diocesan } \\
\text { administrators }\end{array}$ \\
\hline Hands-on participation & 2.56 & 2.55 & 3.63 \\
Demonstration & 2.81 & 2.45 & 2.25 \\
Lecture/discussion & 4.16 & 4.15 & 2.63 \\
Sharing session & 4.17 & 4.45 & 3.38 \\
Make \& take & 4.65 & 5.20 & 5.75 \\
Follow-up in classroom & 4.83 & 5.30 & 5.13 \\
Seminar & 4.89 & 3.70 & 3.38 \\
\hline Note. Low mean is equivalent to most beneficial in-service method.
\end{tabular}

depending on desired outcomes. Teachers ranked school-wide in-service opportunities first, followed by an integrated approach, and a diocesan-wide approach. School administrators agreed with teachers, ranking a school-wide approach as the most effective means of implementing staff development followed by an integrated program. School administrators ranked a diocesan-wide approach slightly lower than teachers. School administrators ranked a schoolwide approach and an integrated approach to implementing staff development slightly higher compared to the rankings of teachers. School administrators also had the largest range in their rankings with a range of 1.31. Diocesan administrators ranked the integrated approach first followed, respectively, by a diocesan-wide and school-wide approach. Diocesan administrators ranked the diocesan-wide approach to implementing staff development 1.00 lower than an integrated program on a scale of 1 to 3 , and a school-wide approach .25 lower for the least effective manner of implementing staff development. Comparing the means of all three groups found that only for the school-wide approach was there a statistically significant difference. Diocesan administrators consistently ranked the school-wide approach as the least effective manner to implement staff development.

\section{Comparison of Most Effective Format for Professional Development}

Teachers $(n=137)$, school administrators $(n=19)$, and diocesan administrators $(n=8)$ were asked to rank preferred in-service format from 1 to 10 with 1 being the most preferred format for professional development and 10 being 
Table 2

Comparison of Most Effective Means of Implementing Staff Development

\begin{tabular}{lccc}
\hline & Teachers & $\begin{array}{c}\text { School } \\
\text { administrators }\end{array}$ & $\begin{array}{c}\text { Diocesan } \\
\text { administrators }\end{array}$ \\
\hline School-wide & 1.54 & 1.50 & 2.50 \\
Integrated & 1.83 & 1.70 & 1.25 \\
Diocesan-wide & 2.62 & 2.80 & 2.25 \\
\hline
\end{tabular}

Note. Low score is equivalent to most effective.

the least preferred format for professional development (see Table 3). The categories in the survey directly correspond to the most often cited obstacles in promoting effective professional development of time, scheduling, and continuing education requirements (Darling-Hammond, 2000; NCTAF, 1996; NECTL, 1994). Teachers preferred half-day sessions, all-day sessions, sessions for university credit, one-hour sessions, and two-hour sessions, respectively. School administrators had more specific mean rankings for their most preferred in-service format and agreed with teachers on their top two preferences. School administrators ranked half-day sessions as their most preferred in-service format, followed by all-day sessions, two-hour sessions, and sessions for university credit, respectively. Diocesan administrators agreed with teachers and school administrators in their top two in-service format preferences, but ranked all-day sessions first and half-day sessions second. Diocesan administrators ranked week-long sessions third, which teachers and school administrators ranked in the bottom half of their preferences. Diocesan administrators also ranked sessions for university credit in the bottom half of preferences, whereas teachers and school administrators ranked it in the top half of preferences. Comparing teachers, school administrators, and diocesan administrators the groups agreed on using half-day and all-day sessions as the top two preferences for in-service formats. After the top two preferences there appears to be some differences in what each group prefers. A significant difference was found among groups for week-long sessions; diocesan administrators preferred a week-long session format more than teachers.

\section{Comparison of Topics Most Needed in Professional Development}

Teachers $(n=139)$, school administrators $(n=20)$, and diocesan administrators $(n=8)$ were asked to rank four topics most needed in professional development, with 1 being the most needed and 4 being the least needed (see 
Table 3

Preferred In-service Formats Mean Rankings

\begin{tabular}{lccc}
\hline & Teachers & $\begin{array}{c}\text { School } \\
\text { administrators }\end{array}$ & $\begin{array}{c}\text { Diocesan } \\
\text { administrators }\end{array}$ \\
\hline Half-day session & 3.83 & 2.79 & 4.25 \\
All-day session & 3.98 & 3.84 & 3.25 \\
University credit & 4.13 & 4.11 & 6.13 \\
One-hour session & 4.15 & 5.42 & 6.00 \\
Two-hour session & 4.34 & 3.89 & 5.13 \\
Self instruction & 5.65 & 6.63 & 7.13 \\
Week-long session & 7.23 & 6.47 & 4.38 \\
Long series & 7.34 & 7.05 & 5.38 \\
Distance learning & 7.44 & 7.47 & 5.50 \\
Weekend session & 7.47 & 7.63 & 7.13 \\
\hline
\end{tabular}

Note. Low mean is equivalent to most preferred format.

Table 4). This supports the research that teachers must be involved in the professional development process from its beginning to its delivery (DarlingHammond, 2000; Holmes Group, 1986, 1995; NCTAF, 1996). Teachers know best what they need in the classroom and the more they are involved in implementing professional development the more effective it will be. Teachers ranked specific content material and instructional strategies, very distinctively, as their top two choices, respectively. School administrators clearly ranked instructional strategies as the topic most needed in professional development. Diocesan administrators agreed with school administrators and ranked instructional strategies as the topic most needed in professional development and latest research on learning second. When comparing mean rankings for teachers, school administrators, and diocesan administrators, instructional strategies seems to be an agreed-upon topic most needed in professional development. There seems to be some disagreement on the need of specific content material and the latest research on learning. It was determined that for specific content material there was a statistically significant difference between teachers and school administrators and between teachers and diocesan administrators. A statistically significant difference was also found between diocesan administrators and school administrators and between diocesan administrators and teachers for latest research on learning. Teachers ranked specific content material as the most needed topic in professional development, 
Table 4

Topics Most Needed in Professional Development Mean Rankings

\begin{tabular}{lccc}
\hline & Teachers & $\begin{array}{c}\text { School } \\
\text { administrators }\end{array}$ & $\begin{array}{c}\text { Diocesan } \\
\text { administrators }\end{array}$ \\
\hline Specific content material & 1.84 & 2.55 & 2.88 \\
Instructional strategies & 1.94 & 1.65 & 1.88 \\
Latest research on learning & 2.91 & 2.95 & 2.00 \\
Classroom management & 3.29 & 2.85 & 3.63 \\
\hline
\end{tabular}

Note. Low mean is equivalent to most needed topic.

whereas school and diocesan administrators did not rank it as highly. Diocesan administrators ranked the latest research on learning as more needed than both teachers and school administrators.

\section{Comparison of Methods of Professional Development}

Teachers $(n=140)$, school administrators $(n=20)$, and diocesan administrators $(n=8)$ were asked to rank seven methods of professional development (see Figure 1) in order of which would be the most likely method to enhance teaching performance with 1 being the most likely method to enhance teaching performance and 7 being the least likely to enhance teaching performance (see Table 5). This supports Guskey's $(1994,2000)$ research on methods that will actually change teacher instruction in the classroom so as to improve student achievement. Teachers ranked training as the most likely method to enhance teaching performance and ranked mentoring second. School administrators agreed with teachers and ranked training first by a greater margin. School administrators ranked observation/assessment second and mentoring a close third. Diocesan administrators ranked mentoring and training first and second, respectively. Study groups and observation/assessment received a more distant third and fourth ranking, respectively. The only statistically significant difference was found among mean rankings for involvement in process; teachers viewed involvement in process as a method most likely to enhance teaching performance more than school administrators.

\section{Discussion}

Teachers believed content-specific experiences and how to use them in the classroom to improve student achievement are their most needed areas in professional development. Catholic secondary teachers believed hands-on 
Table 5

Most Likely Methods to Enhance Teaching Performance Mean Rankings

\begin{tabular}{lccc}
\hline & Teachers & $\begin{array}{c}\text { School } \\
\text { administrators }\end{array}$ & $\begin{array}{c}\text { Diocesan } \\
\text { administrators }\end{array}$ \\
\hline Training & 3.21 & 2.45 & 2.75 \\
Mentoring & 3.76 & 3.50 & 2.50 \\
Individual activities & 3.83 & 4.35 & 5.00 \\
Observation/assessment & 4.01 & 3.20 & 3.50 \\
Inquiry/action research & 4.20 & 4.10 & 5.00 \\
Involvement in process & 4.44 & 5.55 & 4.13 \\
Study groups & 4.47 & 4.75 & 3.25 \\
\hline
\end{tabular}

Note. Low mean is equivalent to most likely method to enhance teaching performance.

participation and demonstration are the top two beneficial in-service methods. This supports findings that teachers find professional development opportunities that provide them with concrete, content-specific material, and instructional strategies they can put directly to use in their classrooms as most beneficial (Fullan, 1993; Guskey, 1994; Little, 1999; Shimabukuro, 2000; Watts \& Castle, 1993). Catholic secondary teachers preferred school-wide in-service programs followed closely by an integrated, diocesan-wide and school-wide approach. A strictly diocesan-wide in-service program was a distant third. This finding also supports the idea that teachers believe school autonomy is important and schools know best what their own teachers need in professional development opportunities (Darling-Hammond, 2000; Guskey, 2000). Teachers also seemed to realize schools cannot provide all the inservice opportunities necessary and a larger diocesan approach is needed. Catholic secondary teachers most preferred in-service format as a half-day session followed by an all-day session, university classes with credit, 1-hour and 2-hour sessions, respectively. Catholic secondary teachers believed training is the method most likely to enhance teaching performance. This corroborates with research that time and scheduling are major issues in professional development (NECTL, 1994).

Catholic school administrators and diocesan administrators believed instructional strategies is the topic most needed in professional development. School administrators believed specific content material is a distant second need in professional development. Diocesan administrators believed the latest research on learning is a close second. Secondary school administrators 
believed demonstration and hands-on participation are the top two most beneficial in-service methods. Diocesan administrators believed demonstration and lecture/discussion are the top two most beneficial in-service methods. School administrators agreed with teachers that school-wide and then an integrated approach are the most effective means of implementing staff development. Diocesan administrators believed an integrated program, followed by a diocesan-wide program, and then a school-wide program are the best ways, respectively, to implement staff development. School and diocesan administrators agreed with teachers that half-day and all-day sessions are the preferred in-service formats. School administrators viewed training, observation/assessment, and mentoring as the top three methods to enhance teaching performance. Diocesan administrators viewed mentoring, training, study groups, and observation/assessment as the top four methods to enhance teaching performance.

There was a significant statistical difference found between diocesan administrators and the other groups on the need for knowing the latest research on learning. Teachers and school administrators did not believe it is as strong a need in professional development. They may not see the need for this information in the immediacy of the classroom demands. Content and instructional strategies were viewed as a greater need for the classroom teacher. Teachers and school administrators agreed that hands-on participation and demonstration are the top two most beneficial in-service methods. Diocesan administrators agreed with the demonstration method but then viewed lecture/ discussion and seminar as the next two most beneficial in-service methods. These results support the idea that teachers and school administrators want professional development to impact the classroom and student learning directly. Diocesan administrators want to help teachers develop a broader view of what and why things are useful in the classroom. This is also supported by the findings that teachers and school administrators favor in-service programs that are school-wide, while diocesan administrators favor an integrated approach (both school-wide and diocesan-wide) followed by a diocesan-wide approach, which was the last choice for school administrators and teachers. Teachers and administrators all favored a half-day or an all-day session for an in-service format. Teachers and administrators agreed that training was a first or second choice as a method to enhance teaching performance. Diocesan administrators viewed study groups more favorably than teachers or school administrators. Mentoring also ranked in the top three choices for all groups as being a method to enhance teaching performance. These findings especially support research that teachers want professional development experiences 
that can be directly applied to the classroom (Abdal-Haqq, 1996; Holmes Group, 1986, 1990; Guskey 1994, 2000).

\section{Recommendations}

\section{Recommendation \#1}

The most significant recommendation that can be made from the literature reviewed and findings presented is that teachers want to be asked what they need to improve student learning and their suggestions must be used when planning professional development experiences. Teachers, and high school teachers specifically, are stereotyped as a difficult audience to reach. If teachers felt more involved in the process of professional development and its implementation, that stereotype might be erased. Teachers must be included in the design, development, implementation, and delivery of professional development.

\section{Recommendation \#2}

From the literature reviewed and survey findings, time and funding issues need to be given primary consideration when planning professional development experiences. All three groups - diocesan administrators, school administrators, and high school teachers - mentioned time and funding as the most significant factors in professional development. Teachers need to be given time to attend workshops, to help plan them, and to be presenters to colleagues. Teachers learn best from other teachers who are working in classrooms with them. Most professional development opportunities are planned by administrators and are done to teachers, not with them. Teachers need to be given time to be a full part of the process of professional development with release time, adjusted teaching schedules, or other creative solutions that can help with time constraints. Funding will always be a part of the education dilemma, and teachers and administrators need to be involved more directly in creating new funding ideas.

\section{Recommendation \#3}

From the data collected from high school teachers, professional development opportunities must focus on content-specific areas and teaching strategies on content material. Teachers are searching for ways to improve their knowledge and better methods to increase student achievement in that specific content area. Professional development opportunities need to focus on these two specific needs that teachers believe are the most important in their work in the classroom. 


\section{Conclusion}

Professional development for secondary educators is a worthy topic of study. Teachers are the catalyst of change in the classroom, and professional development is the tool by which that change can occur. The noblest aim of all professional development is to improve teaching in the classroom so that all students will achieve to their full potential and be inspired by the possibilities of learning both in and outside of the classroom.

\section{References}

Abdal-Haqq, I. (1996). Making time for teacher professional development. Washington, DC: ERIC Clearinghouse on Teaching and Teacher Education. (ERIC Document Reproduction Service No. ED400259)

Beaver, W. (2004). Can "No Child Left Behind" work? American Secondary Education, 32(2), 3-18. Bryk, A. S., \& Holland, P. B. (1984). Research provides perspectives on effective Catholic schools. Momentum, 15(3), 12-16.

Bryk, A. S., Lee, V. E., \& Holland, P. B. (1993). Catholic schools and the common good. Cambridge, MA: Harvard University Press.

Bull, B., Buechler, M., Didley, S., \& Krehbiel, L. (1994). Professional development and teacher time: Principles, guidelines, and policy options for Indiana. Bloomington, IN: Indiana Education Policy Center, School of Education, Indiana University.

Congregation for Catholic Education. (1997). The Catholic school on the threshold of the third millennium. Boston: St. Paul.

Corcoran, T. C. (1995). Transforming professional development for teachers: A guide for state policymakers. Washington, DC: National Governors' Association, Center for Policy Research. (ERIC Document Reproduction Service No. ED384600)

Darling-Hammond, L. (2000). Solving the dilemmas of teacher supply, demand, and standards: How we can ensure a competent, caring, and qualified teacher for every child. New York: National Commission on Teaching \& America's Future.

Fullan, M. (1993). Change forces: Probing the depth of educational reform. New York: Falmer Press. Guskey, T. R. (1994, April). Professional development in education: In search of the optimal mix. Paper presented at the annual meeting of the American Educational Research Association, New Orleans, LA. (ERIC Document Reproduction Service No. ED369181)

Guskey, T. R. (2000). Evaluating professional development. Thousand Oaks, CA: Corwin Press.

Holmes Group. (1986). Tomorrow's teachers: A report of the Holmes Group. East Lansing, MI: Author.

Holmes Group. (1990). Tomorrow's schools: Principles for the design of professional development schools. East Lansing, MI: Author. (ERIC Document Reproduction Service No. ED328533)

Holmes Group. (1995). Tomorrow's schools of education: A report of the Holmes Group. East Lansing, MI: Author.

Little, J. W. (1999, April). Teachers' professional development in the context of high school reform: Findings from a three-year study of restructuring schools. Washington, DC: National Partnership for Excellence and Accountability in Teaching. (ERIC Document Reproduction Service No. ED448154)

Lortie, D. (1975). Schoolteacher: A sociological study. Chicago: University of Chicago Press.

Moore, L. (2000). Staff development in the Catholic school: The caring response of a community. In T. C. Hunt, T. E. Oldenski, \& T. J. Wallace (Eds.), Catholic school leadership: An invitation to lead (pp. 93-104). New York: Routledge Falmer.

National Board for Professional Teaching Standards. (2008). National Board certification statistics. Retrieved March 31, 2009, from http://nbpts.org/about_us/2008_national_board_cert/ national_board_certifica 
National Catholic Educational Association. (2008). Catholic school data. Retrieved March 31, 2009, from http://www.ncea.org/news/CatholicSchoolData.asp

National Center for Accreditation for Teacher Education. (2007). Standards. Retrieved May 31, 2009, from http://www.ncate.org/public/standards.asp? $\mathrm{ch}=4$

National Center for Education Statistics. (2001, May). Public school student, staff, and graduate counts by state: School year 1999-2000, statistics in brief. Retrieved February 14, 2007, from http://nces.ed.gov/pubsearch/pubsinfo.asp?pubid=2001326rev

National Center for Education Statistics. (2007). Fast facts. Retrieved March 31, 2009, from http:// nces.ed.gov/fastfacts/

National Commission on Teaching and America's Future. (1996, September). What matters most: Teaching for America's Future. New York: Author.

National Commission on Teaching and America's Future. (1998, March). State report card U.S. average. Retrieved July 20, 2005, from http://www.tc.columbia.edu/ teachcomm/states/Zavg_tot. htm

National Commission on Teaching and America's Future. (2003, January). No dream denied: A pledge to America's children. New York: Author.

National Education Commission on Time and Learning. (1994, April). Prisoners of time. Washington, DC: Author.

No Child Left Behind Act of 2001, 20 U.S.C. $§ 6301$ (Supp. I 2001).

Rogus, J. F., \& Wildenhaus, C. A. (2000). Ongoing staff development in Catholic schools. In T. C. Hunt, T. E. Oldenski, \& T. J. Wallace (Ed.), Catholic school leadership: An invitation to lead (pp. 157-173). New York: Routledge Falmer.

Shimabukuro, G. (2000). Teaching and learning in the Catholic school: Grounded in sacred soil. In T. C. Hunt, T. E. Oldenski, \& T. J. Wallace (Eds.), Catholic school leadership: An invitation to lead (pp. 113-128). New York: Routledge Falmer.

Shimabukuro, G. (2001). A role analysis based on church documents, dissertations, and recent research. In T. C. Hunt, E. A. Joseph, \& R. J. Nuzzi (Eds.), Handbook of research on Catholic education (pp. 125-146). Westport, CT: Greenwood Press.

Toledo Catholic Diocese. (2003). Schools. Retrieved April 14, 2003, from http://www.cyss.org

Traviss, M. P. (2001). Research on administration, leadership, and governance. In T. C. Hunt, E. A. Joseph, \& R. J. Nuzzi (Eds.), Handbook of research on Catholic education (pp. 99-124). Westport, CT: Greenwood Press.

Watts, G. D., \& Castle, S. (1993). The time dilemma in school restructuring. Phi Delta Kappan, 75(4), 306-310.

Lisa Lucilio is a faculty member at Notre Dame Academy in Toledo, Ohio. Correspondence concerning this article should be sent to Dr. Lisa Lucilio, Notre Dame Academy, 3535 Sylvania Avenue, Toledo, Ohio 43623. 